\title{
Phosphine の作用点について
}

\author{
中 北宏 \\ 農林省食品総合研究所食品保全部貯蔵害虫研究室 \\ 東京都江東区塩浜 1-4-12 \\ (昭和 51 年 3 月 16 日受理)
}

\section{The Inhibitory Site of Phosphine}

\author{
Hiroshi NaKakita \\ Stored-Product Entomology Laboratory, Food Preservation Division, National Food Research \\ Institute, Ministry of Agriculture and Forestry, Koto-ku, Tokyo 135, Japan
}

\begin{abstract}
The inhibitory site of Phosphine $\left(\mathrm{PH}_{3}\right)$ on electron transport chain of rat liver and maize weevil mitochondria was studied. $\mathrm{PH}_{3}$ completely inhibited the respiration of ascorbate+tetramethyl phenyldiamine as substrates under the conditions of ion pumping state $\left(\mathrm{Ca}^{2+}\right.$, Gramicidin), state 3 and uncoupled state (DNP). However, state 4 respiration could not be completely inhibited. The difference spectrum of $\mathrm{PH}_{3}$-added mitochondria clearly showed $\alpha$-cyt $a$ ( $600 \mathrm{~nm}$ for maize weevil, $602 \mathrm{~nm}$ for rat liver) and $\gamma$-cyt $a(445 \mathrm{~nm})$. These results strongly suggested that $\mathrm{PH}_{3}$ acted on cytochrome oxidase. However, the peak positions of $\alpha$-cyt $a$ and $\gamma$-cyt $a$ in both mitochondria shifted to different positions compared with the anaerobic mitochondria and HCN treated mitochondria. Although low concentration of $\mathrm{PH}_{3}(100 \mu \mathrm{M})$ did not give a complete appearance of difference spectrum, the addition of $\mathrm{Ca}^{2+}$ to it gave the clear spectrum. The degree of inhibition of oxidase activity of mitochondria by various concentrations of $\mathrm{PH}_{3}$ was also observed by means of an oxidation rate of the reduced cyt $c$ from horse heart which showed complete inhibition at very low concentration of $\mathrm{PH}_{3}$.
\end{abstract}

ホスフィン $\left(\mathrm{PH}_{3}\right)$ は, 効力, 作業性, 残留などの点で くん蒸戍として優れた性質を有しており（くん蒸戍とし ては $\mathrm{PH}_{3}$ の発生はリン化アルミニウムを主成分とする 固型郕を用いている)，現在，臭化メチル $\left(\mathrm{CH}_{3} \mathrm{Br}\right)$ とな らんで多くの諸国で大量に使用されている.しかし，こ のものは実用化後の歴史が浅いことから，毒性機構につ いては十分解明されていない1)。

Bond et $a l .{ }^{2}$ ，佐藤 ${ }^{3,4)}$ ら，そして著者ら ${ }^{5)}$ は，昆虫の 呼吸に対してこのものは抑制作用をむつことを観察し た。 また，著者ら吕は，ラット肝ミトコンドリアを用い た検討から， $\mathrm{PH}_{3}$ は，呼吸の電子伝達系に阻害作用を有 することを明らかにした。

本報においては， $\mathrm{PH}_{3}$ の電子伝達系阻害点をラット 肝臓とコクゾウ成虫の両ミトコンドリアを用いて, 呼吸 速度とチトクロームのスペクトル变化を中心にして検討
を行なったので報告する。

\section{実 験 方 法}

1. ミトコンドリア

ラット肝ミトコンドリアは, Chance et al.7) の方法で 精製し，また，コクゾウ成虫ミトコンドリアは，著者の 方法8)で精製した。

$\mathrm{PH}_{3}$ 溶液の調製：ゴム栓で封じた Vial 中のエタノー ル(1) +水(4) の混合液中に $\mathrm{PH}_{3}$ を注射器を用いて飽和 させ, $0^{\circ} \mathrm{C}$ に保持し, 実験に平行して経時的に, ガスク ロマトグラフ（島津 $5 \mathrm{~A}, \mathrm{FPD}$ ) にて濃度を測定した。

\section{2. 呼吸量の測定}

ガルバ二電極式溶存酸素計9）（給水化学製）を用いて $25^{\circ} \mathrm{C}$ の呼吸速度を記録観察した。なお，呼吸測定にお ける反応液の最終濃度は, ラット肝では $0.3 \mathrm{M}$ マンニト 
ール, $10 \mathrm{mM} \mathrm{KCl}, 2.5 \mathrm{mM} \mathrm{MgCl}_{2}, 0.25 \mathrm{mM}$ EDTA, $10 \mathrm{mM} \mathrm{KH}_{2} \mathrm{PO}_{4}$ であり, コクゾウでは， ラット肝の反 応液を基本組成として, $\mathrm{MgCl}_{2}$ と $\mathrm{KH}_{2} \mathrm{PO}_{4}$ をそれぞれ $7.0 \mathrm{mM}, 5.0 \mathrm{mM}$ とした（最終 $\mathrm{pH} \mathrm{7.4).} \mathrm{いずれのミ}$ トコンドリアも反応液中に蛋白質濃度として $2 \mathrm{mg} / \mathrm{ml}$ と なるように調製した. $\mathrm{PH}_{3}$ の添加は, マイクロシリンジ を用いた。

\section{3. 差スペクトルの測定}

エンドオンタイプ二波長自記分光光度計（島津 UV 300）を用いて，試料側，対照側のキュベットにそれぞ れ $2.8 \mathrm{mg}$ 蛋白量 $/ \mathrm{ml}$ のミトコンドリアを入れ, ベース ラインを記録後, 試料側に $\mathrm{PH}_{3}$ を加え, 差スペクトル を記録した。

チトクローム酸化酵素活性の反応阻害：還元チトクロ 一ム $c$ (ウマ心臓から) $\mathrm{mg} / 3 \mathrm{ml}$ に一定量の $\mathrm{PH}_{3}$ 溶液 を添加し，ラット肝ミトコンドリア $(0.4 \mathrm{mg}$ 蛋白量 $/ \mathrm{ml})$ をさらに加えて，チトクローム $c$ の酸化速度を分光光度 計にて測定した。 反応液は, $0.5 \mathrm{M} \mathrm{KH}_{2} \mathrm{PO}_{4}, 0.065 \% \mathrm{v} / \mathrm{v}$

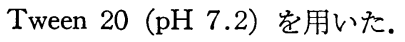

\section{4. 蛋白量の測定}

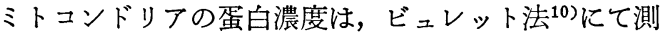
定した。

\section{実験結果および考察}

著者らは，先に(6)，ラット肝ミトコンドリアにおいて， ピルビン酸十リンゴ酸とコハク酸を基質とした実験で, $\mathrm{PH}_{3}$ は, State 4 呼吸に阻害作用を与えず， State 3 呼 吸と $\mathrm{Ca}^{2+}$ や DNP による解放あるいは脱共役呼吸に強

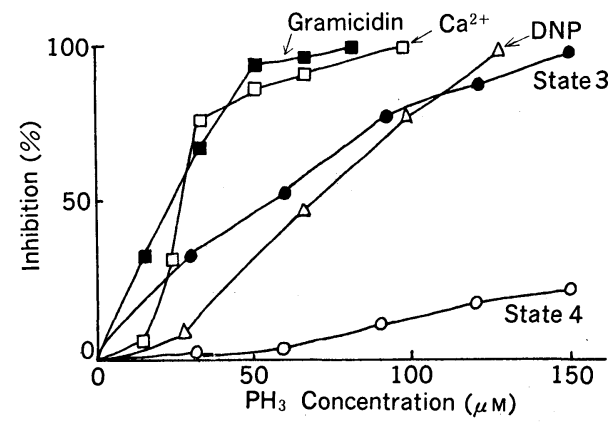

Fig. 1 Inhibitory effect of $\mathrm{PH}_{3}$ on various steady state respiration of rat liver mitochondria. In addition to basic reaction mixture (Fig. 1) were added. $5 \mathrm{mM}$ Ascorbate and $0.1 \mathrm{mM}$ TMPD. The reaction mixtures contained $0.2 \mu \mathrm{g}$ Gramicidin (ion pumping state), $0.4 \mathrm{mM} \mathrm{Ca}^{2+}$ (ion pumping state), $20 \mu \mathrm{M}$ DNP (uncoupled state) and $1 \mathrm{mM}$ ADP (state 3 ). $\quad \mathrm{PH}_{3}$ was added into the respiration system at concentrations indicated.
い阻害効果をみたので，ここでは，ラット肝ミトコンド リアを用いて，アスコルビン酸+TMPD (Tetramethyl Phenyldiamine) 基質とし, 種々呼吸条件下で, $\mathrm{PH}_{3}$ の 濃度に対応した阻害効果を検討した (Fig. 1). $\mathrm{Ca}^{2+}$ ，グ ラミシジンによる解放呼吸, State 3 呼吸, DNP による 脱共役呼吸のいずれも, $\mathrm{PH}_{3}$ の濃度の上昇にともなって

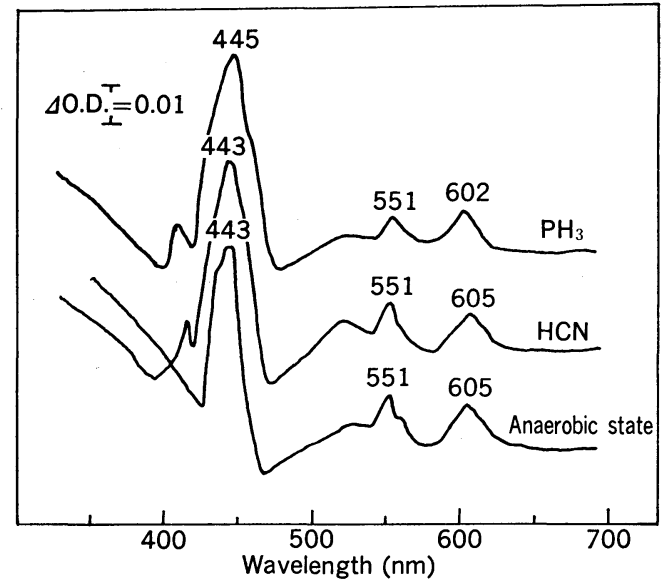

Fig. 2 Difference spectra of rat liver mitochondria induced by $\mathrm{PH}_{3}, \mathrm{HCN}$ and Anaerobic state. All spectra were recorded in same reaction mixture in Fig. 1 at a final concentration of $2.8 \mathrm{mg}$ mitochondrial protein $/ \mathrm{ml}$. Each of $\mathrm{PH}_{3}$ (about $10 \mathrm{mM}$ ) and $\mathrm{HCN}(100 \mu \mathrm{M})$ was added to a sample cuvett, and $\mathrm{ADP}$ $(1 \mathrm{mM})+$ succinate $(8 \mathrm{mM})$ were added to a sample cuvett for the experiment anaerobic state.

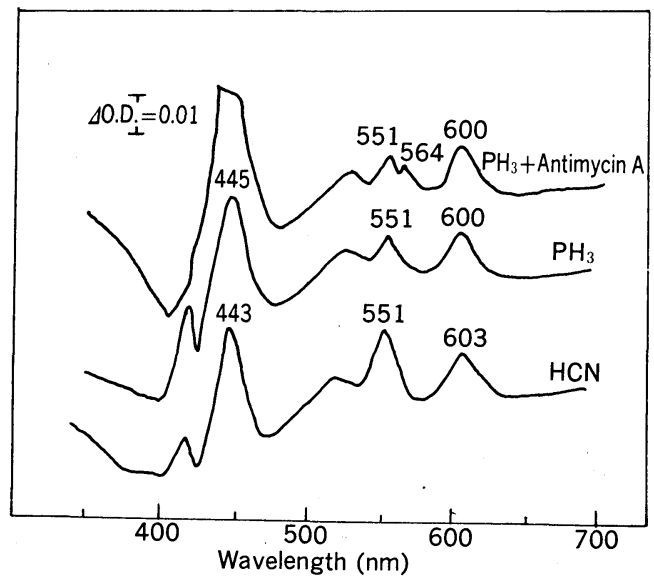

Fig. 3 Difference spectra of maize weevil adult mitochondria induced by $\mathrm{PH}_{3}, \mathrm{PH}_{3}+$ Antimycin $\mathrm{A}$ and $\mathrm{HCN}$.

Experimental conditions were same as Fig. 4. Antimycin A $(10 \mu \mathrm{M})$ was added after $\mathrm{PH}_{3}$ addition to a sample cuvett. 
阻害度は高まったが，State 4 呼吸は，ほとえど阻害を うけなかった。

Fig. 2，3 は，ラット肝，コクゾウ成虫両ミトコンド リアの $\mathrm{PH}_{3}$ による差スペクトルを各種条件における差 スペクトルとともに示した. $\mathrm{PH}_{3}$ の添加は， ラット肝 では, $602 \mathrm{~nm}$ (cyt $a$ の $\alpha$ 吸収帯), $551 \mathrm{~nm}$ (cyt $c$ の $\alpha$ 吸収帯)，445 nm (cyt $a$ の $\gamma$ 吸収帯), コクゾウでは, $600 \mathrm{~nm}$ (cyt $a$ の $\alpha$ 吸収帯), $551 \mathrm{~nm} \mathrm{(cyt} c$ の $\alpha$ 吸収 帯), $445 \mathrm{~nm}$ (cyt $a$ の $\gamma$ 吸収帯) に明瞭な差スペクトル を生じた，しかし，両ミトコンドリアとも，青酸添加の 差スペクトルにくらべ， $\mathrm{PH}_{3}$ の添加は cyt $a$ の $\alpha$ 吸収 帯の位置を $3 \mathrm{~nm}$ 短波長側にずらすとともに $\gamma$ 吸収带の 位置を $2 \mathrm{~nm}$ 長波長側に移動させた。

上記実験では，高濃度の $\mathrm{PH}_{3}$ (約 $10 \mathrm{mM}$ ）を用いた ため $\mathrm{PH}_{3}$ の添加直後にスペクトルの発現をみたが，低 濃度 $\mathrm{PH}_{3}(100 \mu \mathrm{M})$ の添加は, 明瞭な $\alpha$ 吸収帯を生じ なかった (Fig. 4-A)。しかし，この濃度でも， $\mathrm{Ca}^{2+を}$ 添加することによって，短時間内に，尖鋭な cyt $a$ と $c$ の $\alpha$ 吸収帯のスペクトルを生じた (Fig. 4-B). この現 象は，呼吸阻害でみられた $\mathrm{Ca}^{2+}$ の作用をチトクローム レベルで観察したものと考えられる.同様な現象は， $\mathrm{ADP}$ やグラミシジンの添加でも確認された.

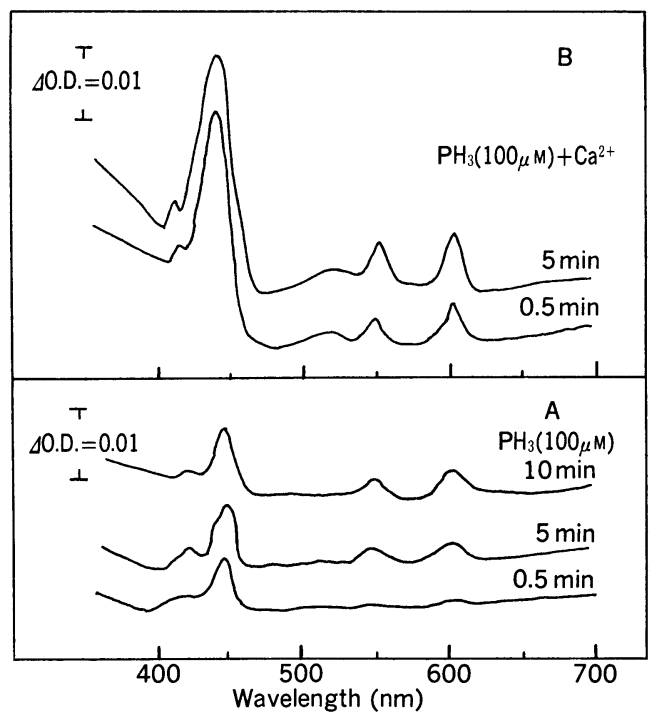

Fig. 4 Effect of $\mathrm{Ca}^{2+}$ on difference spectra of $\mathrm{PH}_{3}$ added rat liver mitochondria.

Experimental conditions were same as Fig. 4. The measurement was started $30 \mathrm{sec}$ after the addition of $\mathrm{PH}_{3}(100 \mu \mathrm{M})$ and $\mathrm{Ca}^{2+}(0.4 \mathrm{mM})$ to rat liver mitochondrial suspension $(2.5 \mathrm{mg}$ protein $/ \mathrm{ml})$ in a sample cuvett.

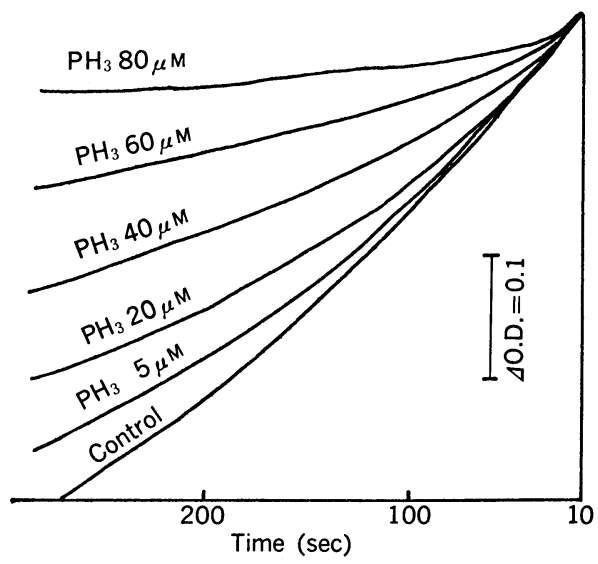

Fig. 5 Effect of $\mathrm{PH}_{3}$ on cytochrome oxidase activity in rat liver mitochondria.

Rat liver mitochondria $(0.4 \mathrm{mg} / \mathrm{ml})$ were suspended in $2.8 \mathrm{ml}$ medium of $50 \mathrm{mM}$ $\mathrm{KH}_{2} \mathrm{PO}_{4}$ and $0.065 \% \mathrm{v} / \mathrm{v}$ Tween 20 . Reduced horse heart cyt $\mathrm{C}(1 \mathrm{mg})$ and $\mathrm{PH}_{3}$ solution were mixed with the mitochondrial medium. Rate of oxidation of cyt $\mathrm{C}$ was followed by monitoring changes of apparent optical density at $550 \mathrm{~nm}$.

ラット肝ミトコンドリア中のチトクローム酸化酵素の $\mathrm{PH}_{3}$ による阻害状態を Fig. 5 に示した. 濃度の上昇に 対応して還元チトクローム $c$ の酸化は抑制され， $80 \mu \mathrm{M}$ の $\mathrm{PH}_{3}$ でチトクローム酸化酵素の活性は完全に阻害さ れた。

上記，呼吸阻害，差スペクトル，チトクローム酸化酵 素の活性阻害の実験事実は, $\mathrm{PH}_{3}$ の電子伝達系におけ る in vitro での阻害 site は下記 scheme に示したごと くチトクローム酸化酵素 (cyt $a$ ) であることを証明する ものである.

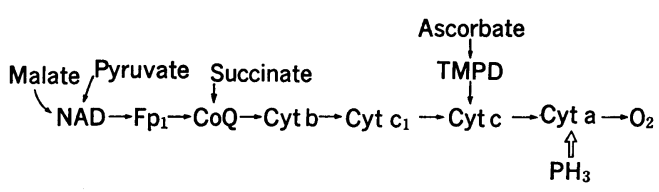

Scheme 1

しかし， $\mathrm{PH}_{3}$ は, State 4 呼吸に作用しにくい特徵を そなえているので，青酸とは阻害様式は異なると予想さ れる. この点に関して, やはり, State 4 呼吸に阻害作用 のないチトクローム酸化酵素阻害剂アザイド $\left(\mathrm{NaN}_{3}\right)^{11)}$ との類似性が考えられる。

なお，最近，著者らとは独立に，Chefurka et al. ${ }^{12)}$ は マウス肝，八エ，グラナリアコクゾウのミトコンドリア を用いて，呼吸に関する $\mathrm{PH}_{3}$ の阻害実験から，このも ののチトクローム酸化酵素阻害を報じている。 
最後に，本論文をまとめるのに種々ご教示，ご助言を いただいた東京農業大学山本出教授ならびに理化学研究 所深見順一博士に感謝の意を表する。 また，本研究に対 して, 終始ご指導をいただいた名古屋大学弥富喜三名誉 教授ならびに斎藤哲夫教授に深甚なる謝意を表する。ま た，本研究の遂行にご便宜をはかっていただいた食品総 合研究所, 食品保全部松浦慎治部長ならびに三井英三室 長，そして，測定法についてご指導をいただいた微生物 第一研究室長伊藤 寛氏に厚くお礼申し上げる.

\section{要 約}

ホスフィン $\left(\mathrm{PH}_{3}\right)$ の電子伝達系における阻害部位をラ ット肝とコクゾウのミトコンドリアを用いて検討した。 $\mathrm{PH}_{3}$ は，アスコルビン酸+TMPD を基質として，イオ ンポンプ $\left(\mathrm{Ca}^{2+}\right.$, グラミシジン), State 3 および脱共役 (DNP) 呼吸を完全に阻害した。しかし，State 4 呼吸に 対しては強い阻害勃果を認めなかった。 $\mathrm{PH}_{3}$ を添加し たミトコンドリアは，チトクローム $a$ の $\alpha$ 吸収帯（二 クゾウでは $600 \mathrm{~nm}$ ，ラット肝では $602 \mathrm{~nm}$ ) と r吸収帯 $(445 \mathrm{~nm})$ に明瞭な差スペクトルを生じた。このことは, $\mathrm{PH}_{3}$ はチトクローム酸化酵素に強く作用していること を証明するものである。しかし，両吸収带のピークの位 置は青酸や嫌気条件のものとは異なっていた。 また， $\mathrm{Ca}^{2+}$ は, 低濃度 $(100 \mu \mathrm{M})$ の $\mathrm{PH}_{3}$ のスペクトル発現を
助長した。一方， $\mathrm{PH}_{3}$ によるミトコンドリア中のチト クローム酸化酵素の活性阻害を, 還元チトクローム $c$ の 酸化速度より観察し, 低濃度の $\mathrm{PH}_{3}$ の強い阻害効果を 確認した。

\section{引用 文 献}

1) R.W. Howe: J. Stored Prod. Res. 10, 167 (1974)

2) E.J. Bond, J.R. Robinson \& C.T. Buckland: J. Stored Prod. Res. 5, 289 (1969)

3）佐藤仁彦, 樋口義弘, 諏訪内正名：防虫科学 $\mathbf{3 8}$, 22 (1973)

4）佐藤仁彦，諏訪内正名：防虫科学 38，213 (1973)

5) H. Nakakita, T. Saito \& K. Iyatomi: J. Stored Prod. Res. 10, 87 (1974)

6) H. Nakakita, Y. Katsumata \& T. Ozawa: $J$. Biochem. 69, 589 (1971)

7) B. Chance \& B. Hagihara: Biochem. Biophys. Res. Commun. 3, 1 (1960)

8) H. Nakakita: Jap. J. Appl. Ent. Zool に投稿中

9）内海耕造，小田环三，倉田研吾，宮原正信，保田 雅夫：蛋白質核酸酵素 14, 621 (1969)

10) E. Layne: "Method in Enzymology," ed. by S.P. Colowick \& N.O. Kapcan, Vol. III, Academic Press Inc., New York, p. 450, 1957

11) F. Palmiert \& M. Klingenberg: European $J$. Biochem. 1, 439 (1967)

12) W. Chefurka, K.P. Kashi \& E.J. Bond: Pestic. Biochem. and Physiol. 6, 65 (1976) 